\title{
Effectiveness of topical corticosteroids in addition to antiviral therapy in the management of recurrent herpes labialis: a systematic review and meta-analysis
}

Nasira Arain ${ }^{1}$, Sharath CV Paravastu ${ }^{1}$ and Mubashir A Arain ${ }^{2^{*}}$

\begin{abstract}
Background: Recurrent herpes labialis (RHL) is one of the most common viral infections worldwide. The available treatments have limited efficacy in preventing the recurrence of ulcerative lesions and reducing the duration of illness. The objective of this review was to identify the effectiveness of topical corticosteroids in addition to antiviral therapy in the treatment of RHL infection.

Methods: A systematic review of randomized clinical trials comparing the efficacy of combined therapy (topical corticosteroids with antiviral) with placebo or antiviral alone in the management of RHL was conducted. MEDLINE, EMBASE, CINAHL, Web of Science, the Cochrane library, and Google Scholar databases were searched. We used RevMan software to conduct the meta-analysis. A fixed-effects model was used for mild to moderate heterogeneity, whereas a random-effects model was used for significant heterogeneity. Heterogeneity among trials was established using $I^{2}$ and chi-square test for heterogeneity.
\end{abstract}

Results: Four studies that fulfilled the selection criteria were included in this review. The total number of participants across included studies was 1,891 (range, 29 to 1,443). The antiviral drugs used were acyclovir, famciclovir, and valacyclovir. Corticosteroids used were $1 \%$ hydrocortisone and $0.05 \%$ fluocinonide. Pooled results showed that patients receiving combined therapy had a significantly lower recurrence rate of ulcerative lesions compared to those in both the placebo group $(\mathrm{OR}, 0.50 ; 95 \% \mathrm{Cl}, 0.39-0.66 ; \mathrm{P}<.001)$ and the antiviral treatment alone group $(\mathrm{OR}, 0.73,95 \% \mathrm{Cl}, 0.58-0.92 ; \mathrm{P}=.007)$. The healing time was also significantly shorter in combined therapy in comparison to placebo $(P<.001)$. However, there were no significant differences in healing time between combined therapy and antiviral alone. The adverse reactions in combined therapy were not significantly different than the placebo group (OR, 1.09; 95\% C, 0.75-1.59; $\mathrm{P}=.85)$.

Conclusion: Treatment with combined therapy is safe and more effective than placebo or antiviral alone for preventing the recurrence of ulcerative lesions in RHL infection.

Keywords: Herpes labialis, Recurrent herpes infection, Cold sores, Corticosteroids and Herpes infection, Meta-analysis

\footnotetext{
* Correspondence: marain@ucalgary.ca

${ }^{2}$ Faculty of Nursing, University of Calgary, 2500 University Drive NW, T2N

1 N4 Calgary, AB, Canada

Full list of author information is available at the end of the article
} 


\section{Background}

Herpes labialis infection is a global public health problem, with 15 to $40 \%$ of the population who experience symptomatic outbreak [1]. Infection rates are high among HIV positive patients; about $95 \%$ of patients are seropositive to herpes simplex type I antigen [2]. In developed countries, one third of the population suffer from recurrent herpes labialis. (RHL) Between 20 to 40\% of adults become infected with herpes simplex infection at some point during their lifetime [3]. Detectable serum antibodies against herpes simplex virus are more prevalent in lower socioeconomic groups [4]. Over the last 20 years, prevalence has increased globally and the prevention of RHL poses a big challenge for the $21^{\text {st }}$ century. The infection is difficult to eradicate and treatment has minimal impact on reduction and prevention of herpes infection. To date, no vaccination has been successful so far in humans to prevent the primary infection of RHL [5].

Herpes simplex labialis (HSL) is a contagious infection that appears as a rash of the skin, usually involving the lips but can affect oral membranes, and is characterized by blisters with pain and occasional itching [6]. There are different sequential stages of lesion including prodrome, redness, papule, vesicular, ulcer, hard crust, dry flaking, and normal skin (complete epithelisation). Ulcerative lesions take longer time to heal, which can adversely impact quality of life [7]. The diagnosis is typically based on clinical history and examination; in some cases, however, specific laboratory tests may be required [8]. The condition is usually mild, but some patients may have severe disease that may affect internal organs or lead to secondary bacterial infections [9].

Current treatment options for HSL include oral antiviral drugs, antiviral ointment or other topical applications (e.g., zinc oxide, zinc sulphate), and anesthetic creams for symptomatic improvement [10]. Treatment needs to be initiated promptly to achieve favorable results. Despite the above mentioned available treatment options, antivirals are commonly used and can slightly reduce the duration of herpes lesions by restraining the multiplication of the virus [11]. However, treatment with antiviral alone is not very effective and in most cases only has a minor effect on the duration of illness. Therefore, researchers have suggested adding corticosteroids to antiviral agents to increase the responsiveness of lesions $[12,13]$ because herpes infection also triggers immune response. However, some controversy exists about the addition of corticosteroids, as steroidal contents may worsen the infection by reducing the natural defense system against the infection [14].

Several countries such as US, Germany, and Netherlands have approved antiviral with topical corticosteroids for the treatment of HSL [15]. However, it has not been licensed yet in other countries such as the UK. Therefore, it is important to understand the role of topical corticosteroid therapy plus anti-viral agent in the management of RHL infection. The purpose of this review was to determine the effectiveness of topical corticosteroids in addition to antiviral therapy (combined therapy) compared to antiviral therapy alone or placebo in the management of RHL infection using a systematic review and meta-analysis.

\section{Methods}

\section{Search methods for identification of studies}

We searched electronic databases including MEDLINE via ovid, EMBASE, CINAHL, Web of Science, and Cochrane Library. Searches were limited to Englishlanguage reports of human studies from 2000, which marked the first clinical trial conducted on topical corticosteroids and antiviral therapy on humans, to 2013.

A combination of medical subject headings $(\mathrm{MeSH})$ and key word searches were used to retrieve the relevant literature in this review. All keywords were entered either with "OR" and "AND" boolean operators and were used with $\$ / *$ where appropriate.

The following MeSH search terms were used:

"herpes simplex"; "herpes simplex virus"; "herpes labialis"; herpes labialis viruses"; "recurrences"; "recurrent herpes"; "topical administration"; "anti-infective agents"; "topical drug administration"; "corticosteroids"; "steroid"; "antiviral agents"; antiviral drugs".

The following key words were used:

herpes simplex; herpes labialis; herpes virus; recurrent herpes labialis; prevention of herpes; treatment of herpes labialis; antiviral for herpes; antiviral + corticosteroid + herpes; topical antiviral for herpes; topical treatment + herpes; herpes labialis treatment + antiviral + corticosteroid.

Additional studies were sought through a review of the reference lists of obtained reports and other relevant reviews on the topic. Grey literature was also searched using Google Scholar and the ClinicalTrials.gov website (http://clinicaltrials.gov).

\section{Inclusion and exclusion criteria}

Original research articles of randomized controlled clinical trials (RCTs) or controlled clinical trials comparing the effectiveness of topical corticosteriods in addition to antiviral (combined therapy) versus antiviral alone or placebo for the treatment of RHL were eligible for inclusion. Pilot clinical trial studies with similar interventions and outcomes were also included. We excluded observational studies and studies that evaluated the treatment for primary herpes labialis, as well as case reports, conference presentations, and editorials. Studies of healthy immuno-competent adolescents (12-17 years) and adults ( $\geq 18$ years) with a history of RHL were included, irrespective of gender, socioeconomic status, and race. 
Two types of interventions were considered for the inclusion: (1) combined therapy versus antiviral therapy alone; or (2) combined therapy versus placebo. The primary outcomes of interest were the development of classical lesions and reduction in pain. Secondary outcomes were healing time, adverse events, and reduction in size of the lesions.

All authors were involved in determining inclusion.

\section{Data collection and analysis}

Data collection and analysis was performed using Review Manager (RevMan Version 5.2, Copenhagen: The Nordic Cochrane Centre, the Cochrane Collaboration, 2012). Data from the studies were extracted using data extraction form. Risk of bias was assessed using the following key domains: randomization, allocation concealment, sample size, blinding (single, double or triple), and attrition rate [16].

Odd ratios (ORs) were used for dichotomous outcomes to measure the strength of association along with $95 \%$ confidence intervals $(\mathrm{CI}) . \mathrm{P}<.05$ was considered significant. For continuous outcomes, mean differences between the groups along with 95\% CIs were measured.

The meta-analysis of continuous data requires means with variance (or SD) to pool data. Outcomes of continuous variables were transformed from medians with interquartile ranges (IQR) to means with $\mathrm{SD}$, using the following formulas [17]:

1. Conversion of median into mean: $\chi \approx a+2 m+b / 4$

2. Conversion of range into variance: $S=b-a / 4=R / 4$

[ $\mathrm{X}=$ mean, $\mathrm{a}=$ smallest value, $\mathrm{b}=$ largest value, $\mathrm{m}=$ median, $\mathrm{S}=$ variance, $\mathrm{R}=$ range].

A fixed-effects model was used for mild to moderate heterogeneity, whereas random-effects model was used for those outcomes when the chi-square test for heterogeneity was significant $(\mathrm{P}<.10)$ and $\mathrm{I}^{2}$ was higher than $50 \%$.

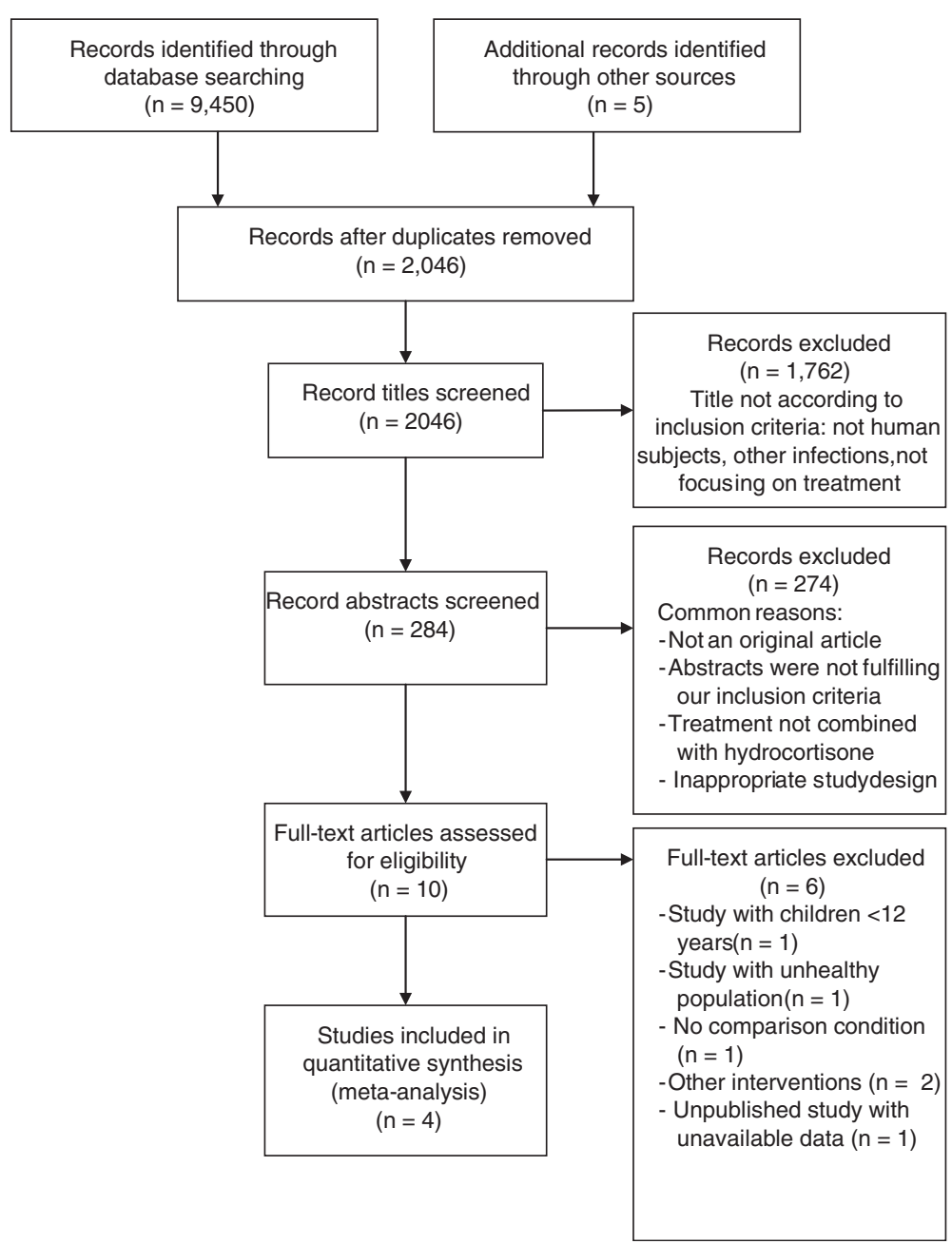

Figure 1 PRISMA flow diagram. 


\section{Results}

\section{Description of the selected studies}

A total of 9,450 studies were originally identified, and 4 were included in the final review (see Figure 1 for PRISMA flow diagram). All 4 selected studies [18-21] were RCTs (see Table 1 for study characteristics). Hull et al. 2010 [18] was a RCT and topical corticosteroids plus antiviral in the management of RHL was evaluated. A total of 89 patients were recruited. There were crossovers and there were no losses to follow up. Evans et al. 2002 [19] conducted a trial on 380 participants to evaluate the effect of ME-609 (topical corticosteroid with antiviral) in comparison to placebo. Hull et al. 2009 [20] was a small trial on 39 participants in which valacyclovir and clobetasol gel were compared with placebo. Spruance et al. 2000 [21] conducted a trial on 29 participants where topical corticosteroid with valacyclovir $2 \mathrm{gm}$ was compared with antiviral alone. The antiviral used was acyclovir in 2 studies [18,19], famciclovir and valacyclovir in each of the other 2 studies [20,21]. The average number of episodes of the RHL in the participants ranged from 4.5 to 5.6 episodes per year.

The risk of bias was assessed in the selected studies. The total number of participants included in the studies was 1,892 (range, 29 to 1,443). All four selected studies appropriately reported the process of randomisation. Most of the randomisation achieved 1:1 treatment to control ratios whilst Hull et al. (2010) [18] performed 2.7:1 for the treatment and placebo group respectively [18]. Allocation concealment was also reported in all four selected studies. Therefore, a minimum risk of selection bias was expected in the selected studies as a result of allocation concealment. The participants as well as personnel involved in providing care (medication) were blinded in all four selected studies. All studies reported the use of identical looking substances in both group in similar packing and labels. Two studies clearly reported the blinding of personnel assessing the outcome [18-20]. On the other hand, it was unclear in two studies [19,21]. The intention to treat analysis was used in all four studies and risk of bias was minimal in relation to drop outs and loss to follow up patients' data.

\section{Effects of interventions}

The development of the ulcerative lesions

Three studies reported on this outcome [18-20]. There was no significant heterogeneity $\left(\mathrm{I}^{2}=20 \%\right)$ found amongst

Table 1 Characteristics of randomized controlled trials included in the review

\begin{tabular}{|c|c|c|c|c|c|}
\hline Study & Setting & Participants (n) & Groups (n) & Male, n (\%) & $\begin{array}{l}\text { Frequency of RHL } \\
\text { (mean episodes/year) }\end{array}$ \\
\hline \multirow[t]{5}{*}{ Hull et al. 2010 [18] } & \multirow{5}{*}{$\begin{array}{l}51 \text { sites in the United } \\
\text { States and } 4 \text { sites in } \\
\text { Canada (July } 2006 \text { to } \\
\text { December 2007) }\end{array}$} & \multirow[t]{5}{*}{1443} & Intervention & \multirow[t]{5}{*}{$406(28)$} & \multirow[t]{5}{*}{5.6} \\
\hline & & & $\begin{array}{l}\text { 1. ME-609 cream (5\% Acyclovir, } 1 \% \\
\text { Hydrocortisone) }(n=601)\end{array}$ & & \\
\hline & & & Control & & \\
\hline & & & $\begin{array}{l}\text { 1. Acyclovir (5\% in ME-609 vehicle) } \\
(n=610)\end{array}$ & & \\
\hline & & & 2. Placebo (vehicle) $(n=232)$ & & \\
\hline \multirow{4}{*}{$\begin{array}{l}\text { Evans et al. } \\
2002 \text { [19] }\end{array}$} & \multirow{4}{*}{$\begin{array}{l}4 \text { major university clinics } \\
\text { in North America }\end{array}$} & \multirow{4}{*}{380} & Intervention & \multirow[t]{4}{*}{$76(20)$} & \multirow[t]{4}{*}{5.3} \\
\hline & & & $\begin{array}{l}\text { 1. ME-609 cream (5\% Acyclovir, } \\
1 \% \text { Hydrocortisone) }(n=190)\end{array}$ & & \\
\hline & & & Control & & \\
\hline & & & 1. Placebo $(n=190)$ & & \\
\hline \multirow[t]{4}{*}{ Hull et al. 2009 [20] } & \multirow{4}{*}{$\begin{array}{l}\text { University of Utah } \\
\text { (August } 2004 \text { to March } \\
\text { 2007) }\end{array}$} & \multirow[t]{4}{*}{39} & Intervention & \multirow[t]{4}{*}{$13(33)$} & \multirow[t]{4}{*}{4.5} \\
\hline & & & $\begin{array}{l}\text { 1. Oral Valacyclovir }(2 \mathrm{~g} 2 \times / \text { day for } 1 \text { day) } \\
\text { plus topical Clobetasol gel }(0.05 \% 2 \times / \text { day } \\
\text { for } 3 \text { days }(n=20)\end{array}$ & & \\
\hline & & & Control & & \\
\hline & & & 1. Placebo $(n=19)$ & & \\
\hline \multirow{4}{*}{$\begin{array}{l}\text { Spruance et al. } \\
2000 \text { [21] }\end{array}$} & \multirow{4}{*}{$\begin{array}{l}\text { University of Utah } \\
\text { Health Sciences Center, } \\
\text { Salt Lake City }\end{array}$} & \multirow[t]{4}{*}{29} & Intervention & \multirow[t]{4}{*}{$14(29)$} & \multirow[t]{4}{*}{5} \\
\hline & & & $\begin{array}{l}\text { 1. Oral Famciclovir (Famvir, } 500 \text { mg } 3 \times / \text { day } \\
\text { for } 5 \text { days) plus topical Fluocinonide }(0.05 \% \\
\text { Lidex Gel } 3 \times / \text { day for } 5 \text { days) }(n=17)\end{array}$ & & \\
\hline & & & Control & & \\
\hline & & & $\begin{array}{l}\text { 1. Famciclovir and topical vehicle control } \\
(\mathrm{n}=12)\end{array}$ & & \\
\hline
\end{tabular}


trials (Figure 2). The chi-square test for heterogeneity was not significant $(\mathrm{P}=.29)$. Meta-analysis showed a statistically significant reduction in the development of ulcerative lesions, demonstrating that the odds of the occurrence of ulcerative lesions were $50 \%$ less likely in the intervention group as compared to placebo (OR, 0.50; 95\% CI, 0.390.66; $\mathrm{P}<.001)$.

Similarly, the comparison of combined therapy with antiviral alone also showed a significant reduction in the development of ulcerative lesions in the intervention arm as compared to the control (Figure 3) (OR, 0.73; 95\% CI, 0.58-0.92; $\mathrm{P}=.007)$. There was moderate heterogeneity among trials $\left(\mathrm{I}^{2}=56 \%\right)$. Chi-square test for heterogeneity was insignificant $(\mathrm{P}=.13)$.

\section{Healing time for ulcerative lesions (complete epithelisation)}

The meta-analysis of 407 patients showed a significant reduction of 1.49 days in the healing time for ulcerative lesions in the combine therapy group in compared to the placebo group (Figure 4) (95\% CI, -1.99 to -0.98 ; $\mathrm{P}<.001)$. This outcome was observed on the based of the healing time from the first sign of lesion until complete epithelisation. All studies showed significant reduction in healing time in the intervention group compared to placebo and there was a moderate heterogeneity between the studies $\left(\mathrm{I}^{2}=53 \%\right)$.

No significant difference was found in the healing time for ulcerative lesions between the combined therapy and the treatment with antiviral alone (mean difference $=-1.68$; $95 \% \mathrm{CI},-4.52$ to 1.16 ) in the pooled data of 357 patients (Figure 5). There was a highly significant heterogeneity between the selected studies $\left(\mathrm{I}^{2}=93 \%\right)$, so the random effect model was used.

\section{The effect of treatment on pain or tenderness in the lesion} In the comparison of topical corticosteroid plus antiviral with placebo, two of the three studies did not show any significant reduction in pain or tenderness in the intervention group as compared to the placebo. However, the overall effect revealed a significant reduction (OR, 0.59; 95\% CI, 0.45-0.77; $\mathrm{P}<.001)$. An effect of a smaller magnitude was observed for reduction in pain and tenderness when the combine therapy was compared with antiviral alone. There was a significant heterogeneity $\left(\mathrm{I}^{2}=67 \%\right)$ between the 2 studies in this analysis. The overall effect using the pooled data of 618 participants showed no significant difference in pain between topical corticosteroid plus antiviral group compared to antiviral alone (OR, 0.32; 95\%CI, 0.03-3.76; $\mathrm{P}=.37$ ).

\section{Adverse reactions}

The most common adverse reactions appeared were dryness, irritation, and stinging symptoms, which were related to topical application and not specifically due to the corticosteroid component. Studies showed no significant difference in proportion of adverse reaction observed between the intervention and the placebo group. There was no heterogeneity between the selected studies $\left(\mathrm{I}^{2}=0 \%\right)$. The overall effect also showed no significant difference between the intervention and the placebo group (OR, 1.09; 95\% CI, 0.75-1.59; $\mathrm{P}=.65$ ).

The odds of the occurrence of adverse reactions were $37 \%$ more likely in the antiviral alone as compared to the combine therapy group; however, the effect was not statistically significant (OR, 1.37; 95\% CI, 0.97-1.95, $\mathrm{P}=.08)$. Heterogeneity between the two groups was not statistically significant $\left(\mathrm{I}^{2}=28 \%\right)$.

\section{Discussion}

To date, this is the first meta-analysis to determine the effect of adding topical corticosteroids in the treatment of RHL. The results of this review show that addition of topical corticosteroids to antiviral therapy has significant benefit compared to either antiviral therapy alone or placebo. The review was conducted on RCTs only, which helped in producing rigorous findings about the effectiveness of adding topical corticosteroids in the treatment of RHL.

This review indicates that the chance of developing ulcerative lesions is reduced in patients who receive topical corticosteroids in addition to antiviral treatment in comparison to placebo or antiviral treatment alone. Evidence

\begin{tabular}{|c|c|c|c|c|c|c|c|c|}
\hline \multirow{2}{*}{$\begin{array}{l}\text { Study } \\
\text { C. Hull } 2009\end{array}$} & \multicolumn{2}{|c|}{$\begin{array}{c}\mathrm{AHC} \\
\text { Events Total }\end{array}$} & \multicolumn{2}{|c|}{$\begin{array}{l}\text { Placebo } \\
\text { Events Total }\end{array}$} & Weight & $\begin{array}{l}\text { Odds Ratio } \\
\text { M-H, Fixed, } 95 \% \mathrm{Cl}\end{array}$ & \multicolumn{2}{|c|}{$\begin{array}{c}\text { Odds Ratio } \\
\text { M-H, Fixed, } 95 \% \mathrm{Cl}\end{array}$} \\
\hline & 10 & 20 & 16 & 19 & $5.0 \%$ & $0.19[0.04,0.85]$ & & \\
\hline C. Hull 2010 & 347 & 601 & 172 & 232 & $63.7 \%$ & $0.48[0.34,0.67]$ & $\mathbf{\square}$ & \\
\hline T.G. Evans 2002 & 50 & 190 & 70 & 190 & $31.3 \%$ & $0.61[0.40,0.95]$ & $\mathbf{\square}$ & \\
\hline Total $(95 \% \mathrm{Cl})$ & & 811 & & 441 & $100.0 \%$ & $0.50[0.39,0.66]$ & $\boldsymbol{\gamma}$ & \\
\hline Total events & 407 & & 258 & & & & & \\
\hline $\begin{array}{l}\text { Heterogeneity: } \mathrm{Cr} \\
\text { Test for overall ef }\end{array}$ & $\begin{array}{l}=2.51, d \\
\mathrm{dt}: Z=5.1\end{array}$ & $\begin{array}{l}\text { df }=2(P \\
14(P<\end{array}$ & $\begin{array}{l}P=0.29 \\
0.0000\end{array}$ & ); $1^{2}=$ & $20 \%$ & & 0 & $\begin{array}{ccc}1 & 10 & 100 \\
\text { Favors [Placebo] }\end{array}$ \\
\hline
\end{tabular}

Figure 2 Forest plot of comparison: topical corticosteroid plus antiviral group versus placebo, outcome: Pooled odds ratio of development of ulcerative lesions. 


\begin{tabular}{|c|c|c|c|c|c|c|c|}
\hline \multirow{3}{*}{$\begin{array}{l}\text { Study } \\
\text { C. Hull } 2010 \\
\text { S.L. Spruance } 2000\end{array}$} & \multicolumn{2}{|c|}{$\begin{array}{c}\text { AHC } \\
\text { Events Tota }\end{array}$} & $\begin{array}{r}\text { AV } \\
\text { Events }\end{array}$ & Total Weight & \multirow{2}{*}{$\begin{array}{l}\text { Odds Ratio } \\
\text { M-H, Fixed, 95\% Cl } \\
0.75[0.59,0.94]\end{array}$} & \multicolumn{2}{|c|}{$\begin{array}{c}\text { Odds Ratio } \\
\text { M-H, Fixed, } 95 \% \mathrm{Cl}\end{array}$} \\
\hline & 347 & 601 & 394 & $61096.9 \%$ & & & \\
\hline & 10 & 17 & 11 & $3.1 \%$ & $0.13[0.01,1.25]$ & & \\
\hline Total $(95 \% \mathrm{Cl})$ & & 618 & & $622100.0 \%$ & $0.73[0.58,0.92]$ & & $\boldsymbol{\nabla}$ \\
\hline Total events & 357 & & 405 & & & & \\
\hline $\begin{array}{l}\text { Heterogeneity: } \mathrm{Chi}^{2}= \\
\text { Test for overall effect }\end{array}$ & $\begin{array}{l}=2.28, d \\
\text { ct: } Z=2.6\end{array}$ & $\begin{array}{l}f=1(P \\
99(P=\end{array}$ & $\begin{array}{l}P=0.13) \\
0.007)\end{array}$ & $; I^{2}=56 \%$ & $\begin{array}{r}0.0 \\
\text { Favo }\end{array}$ & $\begin{array}{c}0.1 \\
\text { rs }[\mathrm{AHC}]\end{array}$ & $\begin{array}{c}10 \\
\text { Favors }[\mathrm{AV}]\end{array}$ \\
\hline
\end{tabular}

Figure 3 Forest plot of comparison: topical corticosteroid plus antiviral group versus antiviral alone, outcome: Pooled odds ratio for development of ulcerative lesions.

shows that the treatment with antiviral alone decreases the duration of ulcerative lesions in herpes labialis [22,23]. However, in most cases antiviral treatment alone does not prevent the development of ulcerative lesion [12].

Pain is another important determinant of the morbidity in RHL [6]. A 24\% reduction in the development of pain in the lesion was an important outcome observed. One study reported a $26 \%$ faster improvement in pain among those patients who received topical penciclovir than those who received a placebo [23]. However, a review of 10 antiviral studies showed that none of them had any significant effect on pain reduction [10]. Furthermore, topical anesthetic treatment alone also did not show any significant impact on pain reduction [24]. Photodynamic therapy is effective in relieving pain in the lesions [25].

The adverse reactions were lower in corticosteroids group than those appeared in the antiviral group alone. A non-randomized clinical trial to determine the safety and tolerance of topical corticosteroids plus antiviral in adolescents found that the treatment was well tolerated and safe [13]. Studies on animals have also shown that the treatment with acyclovir with hydrocortisone is superior to antiviral alone without any significant adverse reactions [26].

The healing time was significantly reduced (around 1.5 days) in the treatment group in comparison to placebo. A review on topical acyclovir revealed that 9 of 13 studies did not show any significant effect on healing time, while 4 studies demonstrated significant reductions ranging from 0.5 to 2 days [27]. Treatment with topical penciclovir alone reduced healing time by 0.5 days in two clinical trials of 3,057 and 1,573 patients [28,29]. Oral antiviral treatment with famciclovir has shown a reduction of approximately 2 days in healing time [30]. Another trial with valacyclovir 2 grams on 1,524 patients found a median reduction in healing time by 1.5 days [31], which is comparable to the reduction in the healing time with topical corticosteroids plus antiviral demonstrated in this review.

There are a number of limitations of this study. First, the meta-analysis in this study was conducted on a small number of studies, which is likely attributable to the limited availability of topical corticosteroid plus antiviral treatment. The statistical tests to identify publication bias could not be performed due to the small number of studies in the review. Second, the selected studies used different form and type of antivirals (oral and topical). The topical antiviral agents that are most commonly recommended to treat RHL include acyclovir 5\% cream, penciclovir $1 \%$ cream and docosanol $10 \%$ cream. Most of these preparations need to be applied every 2 hours from the time of prodrome until complete healing [32]. Unlike topical agents, systemic medications enable greater drug exposure, rapid access to site of viral replication, better biocompatibility, less frequent dosing, and improved compliance. Systemic antiviral agents may be administered orally or intravenously. Acyclovir has a short half-life and multiple doses are required to maintain an optimum drug levels in serum. Famciclovir and

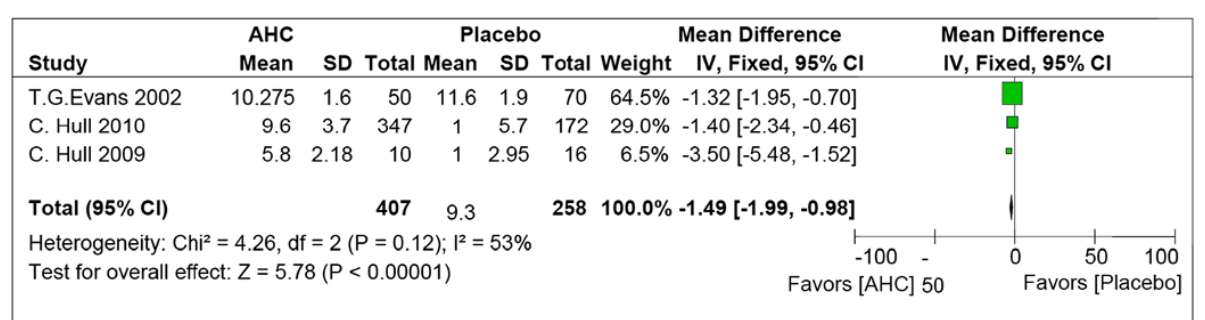

Figure 4 The comparison of effect of corticosteroid plus antiviral and placebo on the healing time for ulcerative lesions from the first sign until complete epithelisation. 


\begin{tabular}{|c|c|c|c|c|c|c|}
\hline Study & $\begin{array}{r}\text { AHC } \\
\text { Mean SD }\end{array}$ & Total & $\begin{array}{c}\text { AV } \\
\text { Mean SD }\end{array}$ & Total Weight & $\begin{array}{l}\text { Mean Difference } \\
\text { t IV, Random, } 95 \% \text { C }\end{array}$ & $\begin{array}{l}\text { Mean Difference } \\
\text { IV, Random, } 95 \% \mathrm{CI}\end{array}$ \\
\hline C. Hull 2010 & 9.63 .7 & 347 & 9.94 .3 & $39452.4 \%$ & $-0.30[-0.88,0.28]$ & $\square$ \\
\hline S.L. Spruance 2000 & 7.21 .5 & 10 & 10.41 .7 & $1147.6 \%$ & $-3.20[-4.57,-1.83]$ & 5 \\
\hline Total $(95 \% \mathrm{Cl})$ & & 357 & & $405100.0 \%$ & \% $\quad-1.68[-4.52,1.16]$ & 1 \\
\hline \multicolumn{6}{|c|}{$\begin{array}{l}\text { Heterogeneity: } \mathrm{Tau}^{2}=3.92 ; \mathrm{Chi}^{2}=14.65, \mathrm{df}=1(\mathrm{P}=0.0001) ; \mathrm{I}^{2}=93 \% \\
\text { Test for overall effect: } Z=1.16(\mathrm{P}=0.25)\end{array}$} & 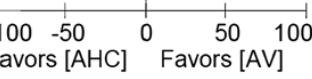 \\
\hline
\end{tabular}

Figure $\mathbf{5}$ The comparison of effect of corticosteroid plus antiviral and antiviral alone on the healing time for ulcerative lesions from the first sign until complete epithelisation.

valacyclovir have greater bioavailability and are more convenient for patients [33]. The reduction in healing time for oral antiviral treatment is generally higher than topical antivirals; this may have had an impact on the outcomes of this study. Finally, 2 studies used ultravioletinduced cold sores, which may lead to more severe outbreaks. Ultraviolet light is known to be a stimulus for the reactivation of herpes simplex virus. Ultravioletinduced cold sores may develop very rapidly $[34,35]$. However, in this study, we found that the combination therapy was equally effective for the ultraviolet-induced cold sores.

\section{Conclusion}

The addition of the steroidal component along with antivirals improves treatment of RHL. Adverse reactions are lower in topical corticosteroid plus antivirals treatment than treatment with antiviral alone. Thus, the treatment with topical corticosteroid plus antiviral alone is safe and more effective in preventing the development of ulcerative lesions than antiviral alone or placebo. The healing time may not be further reduced with topical corticosteroid plus antiviral than with antiviral treatment alone.

\section{Competing interests}

The authors declare that they have no competing interests.

\section{Authors' contributions}

NA and SP planned the overall study. MA participated in data collection and reviewing papers for the study. NA, MA and SP performed data analysis. All authors read and approved the final manuscript.

\section{Authors' information}

NA (MBBS, MPH) is a Postgraduate student at the University of Sheffield, UK. SP (MBBS, MRCS, PGDip) is a Lecturer at the School of Health and Related Research, Section of Health Economics and Decision Science, University of Sheffield, UK. MA (MBBS, MPH, PhD) is a Postdoctoral Fellow at the Faculty of Nursing, University of Calgary, Canada.

\section{Acknowledgements}

We acknowledge Jill Norris, Faculty of Nursing, University of Calgary, for her support in editing the manuscript.

\section{Author details}

'School of Health and Related Research, The University of Sheffield, Sheffield, UK. ${ }^{2}$ Faculty of Nursing, University of Calgary, 2500 University Drive NW, T2N 1 N4 Calgary, AB, Canada.
Received: 1 September 2014 Accepted: 10 February 2015

Published online: 21 February 2015

\section{References}

1. Fatahzadeh M, Schwartz R. Human herpes simplex virus infections: epidemiology, pathogenesis, symptomatology, diagnosis, and management. J Am Acad Dermatol. 2007;57(5):737-63. Available at: http://www.ncbi.nlm. nih.gov/pubmed/17939933 [Accessed: 15th June 2014].

2. Skulason S, Peter Holbrook W, Thormar H, Gunnarsson G, Kristmundsdottir T. A study of the clinical activity of a gel combining monocaprin and doxycycline: a novel treatment for herpes labialis. J Oral Pathol Med. 2012:41(1):61-7.

3. Worrall, G. Herpes labialis. BMJ Clin Evid. 2009 Sep 23;2009. Available at: http://www.ncbi.nlm.nih.gov/pubmed/21726482 [Accessed: 19th June 2014].

4. Xu F, Sternberg M, Kottiri B, Mcquillan G, Lee F, Nahmias A, et al. Trends in Herpes Simplex Virus Type 1 and Type 2 Seroprevalence in the United States. JAMA. 2006;296(8):964-73. Available at: http://jama.jamanetwork. com/article.aspx?articleid=203222 [Accessed: 5th July 2014].

5. Field $\mathrm{H}$, Vere Hodge R. Recent developments in anti-herpesvirus drugs. $\mathrm{Br}$ Med Bull. 2013;106:213-49.

6. Scoular A, Norrie J, Gillespie G, Mir N, Carman W. Longitudinal study of genital infection by herpes simplex virus type 1 in Western Scotland over 15 years. Br Med J. 2002;324(7350):1366-13667. Available at: http://www. ncbi.nlm.nih.gov/pmc/articles/PMC115212/ [Accessed: 20th June 2014].

7. Harmenberg J, Oberg B, Spruance S. Prevention of ulcerative lesions by episodic treatment of recurrent herpes labialis: A literature review. Acta Derm Venereol. 2010;90(2):122-30. Available at: http://www.ncbi.nlm.nih. gov/pubmed/20169294 [Accessed: 5th Aug 2013].

8. Arduino P, Porter S. Herpes Simplex Virus Type 1 infection: overview on relevant clinico-pathological features. J Oral Pathol Med. 2008;37(2):107-21. Available at: http://www.ncbi.nlm.nih.gov/pubmed/18197856 [Accessed: 2nd Feb 2013].

9. Worrall G. Herpes labialis. Clin Evid. 2005;14:2050-7.

10. Opstelten W, Neven A, Eekhof J. Treatment and prevention of herpes labialis. Can Fam Physician. 2008;54(12):1683-7. Available at: http://www. ncbi.nlm.nih.gov/pmc/articles/PMC2602638/ [Accessed: 9th Apr 2013].

11. Raborn G, Grace M. Recurrent herpes simplex labialis: selected therapeutic options. J Can Dental Assoc. 2003;69(8):498-503. Available at: https://www. ncbi.n/m.nih.gov/m/pubmed/12954137/?i=4\&from=/15293697/related [Accessed: 17th June 2013].

12. Hull C, Brunton S. The role of topical $5 \%$ acyclovir and $1 \%$ hydrocortisone cream (Xerese ${ }^{\mathrm{T} M}$ ) in the treatment of recurrent herpessimplex labialis. Postgrad Med. 2011;122(5):1-6. Available at: http://www.ncbinlm.nih.gov/ pubmed/20873400 [Accessed: 4th Feb 2013].

13. Strand A, Böttiger D, Gever L, Wheeler W. Safety and tolerability of combination acyclovir $5 \%$ and hydrocortisone $1 \%$ cream in adolescents with recurrent herpes simplex labialis. Pediatr Dermatol. 2012;29(1):105-10. Available at: http://www.ncbi.nlm.nih.gov/pubmed/22004219 [Accessed: 9th Feb 2013].

14. Aciclovir + hydrocortisone. Herpes labialis: a topical antiviral drug perhaps, but not a steroid. Prescrire Int. 2011 Sep;20(119):205-7. Available at: http:// www.ncbinlm.nih.gov/pubmed/21954513 [Accessed: 15th Feb 2015].

15. Scheinfeld N. New to the clinic: Therapeutic Review 2009-2010. SKINmed. 2010;8(6):348-9. Available at: http://skinmedjournal.com/skinmed_v8i6_I. pdf\#page $=42$ [Accessed: 5th Sep 2013].

16. Higgins JP, Altman DG, Gotzsche PC, et al. The Cochrane Collaboration's tool for assessing risk of bias in randomised trials. BMJ 2011;343:d5928. 
Available at: http://www.ncbi.nlm.nih.gov/pmc/articles/PMC3196245 [Accessed: 15th Feb 2015].

17. Hozo S, Djulbegovic B, Hozo I. Estimating the mean and variance from the median, range, and the size of a sample. BMC Medical Research Methodology.2005;5:13. Available at: http://www.biomedcentral.com/14712288/5/13 [Accessed: 6th Aug 2013].

18. Hull C, Harmenberg J, Arlander E, Aoki F, Bring J, Darpö B, et al. Early treatment of cold sores with topical ME-609 decreases the frequency of ulcerative lesions: a randomized, double-blind, placebo-controlled, patientinitiated clinical trial. J Am Acad Dermatol. 2010;64(4):696.e1-1. Available at http://www.ncbi.nlm.nih.gov/pubmed/20851499 [Accessed: 05th Mar 2013].

19. Evans T, Bernstein D, Raborn G, Harmenberg J, Kowalski J, Spruance S, et.al. Double-blind, randomized, placebocontrolled study of topical 5\% acyclovir, $1 \%$ hydrocortisone cream (ME-609) for treatment of UV radiation-induced herpes labialis. Antimicrobial agents and chemotherapy. 2002;46(6):1870-4. Available at: http://www.ncbi.nlm.nih.gov/pubmed/12019102 [Accessed: 20th Mar 2013].

20. Hull C, Mckeough M, Sebastian K, Kriesel J, Spruance S. Valacyclovir and topical clobetasol gel for the episodic treatment of herpes labialis: a patient-initiated, double-blind, placebo-controlled pilot trial. J Eur Acad Dermatol Venereol. 2009;23(3):263-7. Available at: http://www.ncbi.nIm.nih. gov/pubmed/19143902 [Accessed: 18th May 2013].

21. Spruance S, Mckeough M. Combination treatment with famciclovir and a topical corticosteroid gel versus famciclovir alone for experimental ultraviolet radiation-induced herpes simplex labialis: a pilot study. J Infect Dis. 2000;181(6):1906-10. Available at: http://www.ncbi.nlm.nih.gov/ pubmed/10837169 [Accessed: 2nd May 2013].

22. Spruance $S$, Nett $R$, Marbury $T$, Wolff $R$, Johnson J, Spaulding $T$, et.al. Acyclovir cream for the treatment of herpes simplex labialis: results of two randomized, double-blind, vehicle-controlled, multicenter clinical trials. Antimicrob Agents Chemother. 2002;46(7):2238-43. Available at: http:// www.ncbi.nlm.nih.gov/pubmed/12069980 [Accessed: 6th Aug 2013].

23. Raborn G, Martel A, Lassonde M, Lewis M, Boon R, Spruance S, et.al. Effective treatment of herpes simplex labialis with penciclovir cream: combined results of two trials. J Am Dental Assoc. 2002;133(3):303-9. Available at: http://www.ncbi.nlm.nih.gov/pubmed/11934185 [Accessed: 7th Aug 2013].

24. Kaminester L, Pariser R, Pariser D, Weiss J, Shavin J, Landsman L, et al. A double-blind, placebo-controlled study of topical tetracaine in the treatment of herpes labialis. J Am Acad Dermatol. 1999; 41(6):996-1001. Available at: http://www.ncbi.nlm.nih.gov/pubmed/10570387 [Accessed: 15th Apr 2013].

25. Sperandio F, Marotti J, Aranha A, Eduardo Cde P. Photodynamic therapy for the treatment of recurrent herpes labialis: preliminary results. Gen Dent. 2009;57(4):415-9. Available at: http://www.ncbi.nlm.nih.gov/pubmed/ 19903625 [Accessed: 6th Aug 2013]

26. Harmenberg J, Awan A, Alenius S, Ståhle L, Erlandsson A, Lekare G, et al. Augustsson E, Larsson T, Wikström A, Stierna P, Field H, Larsson A. ME-609: a treatment for recurrent herpes simplex virus infections. Antivir Chem Chemother. 2003;14(4):205-15. Available at: http://www.ncbi.nlm.nih.gov/ pubmed/14582849 [Accessed: 4th Aug 2013].

27. Woo S, Challacombe S. Management of recurrent oral herpes simplex infections. Oral Surg Oral Med Oral Pathol Oral Radiol Endod. 2007;103(S12): e1-18. Available at: http://www.ncbi.nlm.nih.gov/pubmed/17379150 [Accessed: 4th Aug 2013].

28. Raborn G, for the Penciclovir Topical Collaborative Study Group. Paper presented at Thirty-sixth Interscience Conference on Antimicrobial Agents and Chemotherapy, New Orleans, La. 1996.

29. Spruance S, Rea T, Thoming C, Tucker R, Saltzman R, Boon R, et.al. Penciclovir cream for the treatment of herpes simplex labialis. A randomized, multicenter, double-blind, placebo-controlled trial. Topical Penciclovir Collaborative Study Group. J Am Med Assoc. 1997;277(17):1374-9. Available at: http://www.ncbi. nlm.nih.gov/pubmed/9134943 [Accessed: 2nd Aug 2013].

30. Spruance S, Bodsworth N, Resnick H, Conant M, Oeuvray C, Gao J, et al. Single-dose, patient-initiated famciclovir: a randomized, double-blind, placebo-controlled trial for episodic treatment of herpes labialis. J Am Acad Dermatol. 2006;55(1):47-53. http://www.ncbi.nlm.nih.gov/pubmed/16781291 [Accessed: 19 Mar 2013].

31. Spruance S, Jones T, Blatter M, Vargas-Cortes M, Barber J, et al. High-dose, short-duration, early valacyclovir therapy for episodic treatment of cold sores: results of two randomized, placebo-controlled, multicenter studies.
Antimicrob Agents Chemother. 2003;47(3):1072-80. Available at: http:// www.ncbin.nlm.nih.gov/pubmed/12604544 [Accessed: 12th Mar 2013].

32. Stoopler ET, Balasubramaniam R. Topical and systemic therapies for oral and perioral herpes simplex virus infections. J Calif Dent Assoc. 2013;41(4):259-62.

33. Balfour Jr HH. Antiviral drugs. N Engl J Med. 1999;340:1255-68.

34. Rooney JF, Bryson Y, Mannix ML, Dillon M, Wohlenberg CR, Banks S, et al. Prevention of ultraviolet-light-induced herpes labialis by sunscreen. Lancet. 1991;338(8780):1419-22.

35. Spruance SL. Pathogenesis of herpes simplex labialis: experimental induction of lesions with UV light. J Clin Microbiol. 1985;22(3):366-8.

\section{Submit your next manuscript to BioMed Central and take full advantage of:}

- Convenient online submission

- Thorough peer review

- No space constraints or color figure charges

- Immediate publication on acceptance

- Inclusion in PubMed, CAS, Scopus and Google Scholar

- Research which is freely available for redistribution

Submit your manuscript at www.biomedcentral.com/submit 